\title{
Protein Phosphatase 2A Regulates bim Expression via the Akt/FKHRL1 Signaling Pathway in Amyloid- $\beta$ Peptide- Induced Cerebrovascular Endothelial Cell Death
}

\author{
Ke-Jie Yin, ${ }^{1}$ Chung Y. Hsu, ${ }^{1,2}$ Xiao-Yan Hu, ${ }^{1}$ Hong Chen, ${ }^{1}$ Sha-Wei Chen, ${ }^{1}$ Jan $\mathrm{Xu},{ }^{1}$ and Jin-Moo Lee ${ }^{1}$ \\ ${ }^{1}$ Department of Neurology and the Hope Center for Neurological Disorders, Washington University School of Medicine, St. Louis, Missouri 63110, and \\ ${ }^{2}$ Taipei Medical University, Taipei 110, Taiwan
}

\begin{abstract}
Amyloid- $\beta$ peptide (A $\beta$ )-induced death in cerebral endothelial cells (CECs) is preceded by mitochondrial dysfunction and signaling events characteristic of apoptosis. Mitochondria-dependent apoptosis engages Bcl-2 family proteins, especially the BH3-only homologues, which play a key role in initiating the apoptotic cascade. Here, we report that the expression of bim, but not other BH3-only members, was selectively increased in cerebral microvessels isolated from 18-month-old APPsw (Tg2576) mice, a model of cerebral amyloid angiopathy (CAA), suggesting a pivotal role for Bim in $\mathrm{A} \beta$-induced cerebrovascular degeneration in vivo. A similar expression profile was observed in A $\beta$-treated CECs. Furthermore, $\mathrm{A} \beta$ induction of bim expression involved a pro-apoptotic transcription factor, FKHRL1. FKHRL1 bound to a consensus sequence in the bim promoter region and was activated by A $\beta$ before bim expression. FKHRL1 activity was negatively regulated by phosphorylation catalyzed by Akt, an anti-apoptotic kinase. Akt upregulation by adenoviral gene transfer inhibited $\mathrm{A} \beta$-induced FKHRL1 activation and bim induction. In addition, $\mathrm{A} \beta$ increased the activity of protein phosphatase $2 \mathrm{~A}$ (PP2A), a ceramide-activated protein phosphatase. Suppression of PP2A activity by RNA interference or a specific inhibitor, okadaic acid, effectively suppressed $\mathrm{A} \beta$-induced Akt inactivation and FKHRL1 activation, leading to an attenuation of bim expression and cell death in CECs. Coimmunoprecipitation experiments revealed that $\mathrm{A} \beta$ enhanced the binding of the PP2A regulatory subunit PP2AC $\alpha \beta$ to Akt. These results implicate PP2A as an early regulator of A $\beta$-induced bim expression and CEC apoptosis via the Akt/FKHRL1 signaling pathway. We raise the possibility that this pathway may play a role in cerebrovascular degeneration in CAA.
\end{abstract}

Key words: amyloid $\beta$ peptide; apoptosis; bim; ceramide-activated protein phosphatases; cerebral endothelial cells; FKHRL1

\section{Introduction}

Amyloid- $\beta$ peptide $(\mathrm{A} \beta)$ has been implicated in the pathogenesis of Alzheimer's disease (AD) (Wisniewski and Wegiel, 1995; Yankner, 1996). In addition to parenchymal accumulation and neuronal degeneration in AD brains (Yankner et al., 1989; Behl et al., 1994), A $\beta$ also accumulates in the cerebrovascular wall of elderly individuals with or without $\mathrm{AD}$, leading to cerebral amyloid angiopathy (CAA) (Perlmutter et al., 1994; Wisniewski et al., 2000). A $\beta$ induces death of cerebral endothelial cells (CECs) (Price et al., 1997; Preston et al., 1998) with features suggestive of apoptosis (Blanc et al., 1997; Suo et al., 1997; Xu et al., 2001; Yin et al., 2002b). We have recently reported that $\mathrm{A} \beta$-induced CEC apoptosis was associated with the induction of Bim, an apoptotic initiator, to release pro-apoptotic mitochondrial molecules into the cytosol (Yin et al., 2002b). Bim belongs to the "BH3-only

\section{Received Aug. 15, 2005; accepted Dec. 22, 2005}

This work was supported by National Institutes of Health Grants K08 NS002190 and NS40525 (J.-M.L.), American Heart Association Grants $0365378 Z$ (K.-J.Y.) and $0460066 Z$ (J.-M.L.), and National Science Council Grant 93-2321B-038-003 (C.Y.H.).

Correspondence should be addressed to Dr. Jin-Moo Lee, Department of Neurology, Campus Box 8111, Washington University School of Medicine, 660 South Euclid Avenue, St. Louis, M0 63110. E-mail: leejm@neuro.wustl.edu.

DOI:10.1523/JNEUROSCI.5103-05.2006

Copyright $\odot 2006$ Society for Neuroscience $\quad$ 0270-6474/06/262290-10\$15.00/0 proteins," a subgroup of Bcl-2 apoptotic regulators that contain only one of the bcl-2 homology regions $(\mathrm{BH} 3)$. In response to apoptotic stimuli, $\mathrm{BH} 3$-only proteins translocate to the mitochondrial membrane from other cellular compartments to interfere with the function of antiapoptotic Bcl-2 family members to initiate apoptosis (Huang and Strasser, 2000). Although some $\mathrm{BH} 3$-only proteins may be post-translationally modified by upstream death signaling events to trigger translocation (Dijkers et al., 2000; Huang and Strasser, 2000; Whitfield et al., 2001), others such as Bim are transcriptionally regulated to initiate apoptosis (Bouillet et al., 2001). Bim expression is regulated by transcription factors of the forkhead in rhabdomyosarcoma (FKHR) family, which includes FKHR (also known as FOXO1) and FKHRL1 (FOXO3a) (Burgering and Kops, 2002; Gilley et al., 2003). Forkhead protein activity, in turn, is negatively regulated via phosphorylation by the survival promoting kinase Akt (Brunet et al., 1999; Tang et al., 1999).

Akt maintains cell viability by phosphorylating pro-apoptotic mediators including forkhead proteins (Brunet et al., 1999; Zheng et al., 2000). Dephosphorylation of Akt by protein phosphatases disinhibits pro-apoptotic proteins to initiate apoptotic processes (Ugi et al., 2004; Gao et al., 2005). Protein phosphatase 2A (PP2A), a member of the ceramide-activated protein phosphatases (CAPPs) family, is a serine/threonine-specific protein 
phosphatase that regulates the activities of several major protein kinase families, including Akt to drive apoptotic processes (Millward et al., 1999; Silverstein et al., 2002).

We have shown previously that $\mathrm{A} \beta$ cytotoxicity is mediated by ceramide (Xu et al., 1998; Lee et al., 2004; Yang et al., 2004), a pro-apoptotic lipid mediator (Obeid et al., 1993; Brugg et al., 1996; Mangoura and Dawson, 1998). This A $\beta$-ceramide death pathway involves the activation of neutral sphingomyelinase (nSMase) (Lee et al., 2004; Yang et al., 2004), a ceramidesynthesizing enzyme. We also demonstrated that $\mathrm{A} \beta$-induced CEC death is associated with the rapid induction of Bim and the activation of subsequent apoptotic pathways (Yin et al., 2002b). The link between these two cell death pathways remains to be established. In the present study, we report that activation of PP2A is the intermediate step between the $\mathrm{A} \beta$-ceramide cascade and the subsequent inactivation of Akt, activation of FKHRL1, and upregulation of bim.

\section{Materials and Methods}

Mouse CEC primary cultures. Mouse CECs were prepared as described previously (Xu et al., 1992). Briefly, mouse CECs migrating from isolated microvessel preparations were pooled to form a proliferating cell culture that was maintained in DMEM, with high glucose and L-glutamine supplemented with $10 \% \mathrm{FBS}, 0.5 \mathrm{mg} / \mathrm{ml}$ heparin, and $75 \mu \mathrm{g} / \mathrm{ml}$ endothelial cell growth supplements. Mouse CECs (between passages 4 and 15) uniformly positive for factor VIII, vimentin, and characteristic bradykinin receptors ( $>95 \%$ endothelial cell purity) were grown to $85-95 \%$ confluence before use (Xu et al., 1992).

Treatment with $A \beta$ and other chemicals. $\mathrm{A} \beta_{1-40}$ is the major component of amyloid deposits in cerebrovascular vessels in CAA. However, in most experimental systems, the biological effects of fragment $\mathrm{A} \beta_{25-35}$ are comparable (Loo et al., 1993; Behl et al., 1994). We have shown previously that $\mathrm{A} \beta_{25-35}$ has approximately the same potency as $\mathrm{A} \beta_{1-40}$ in inducing cell death in CECs (Xu et al., 2001; Yin et al., 2002b). Based on these data, we used $\mathrm{A} \beta_{25-35}$ in most experiments in this study and confirmed key findings with $A \beta_{1-40}$. Several protocols for $A \beta$ aggregation were used in the present studies. For $\mathrm{A} \beta_{25-35}$ (Sigma, St. Louis, MO), a 1 mM peptide stock solution was prepared in sterile double-distilled $\mathrm{H}_{2} \mathrm{O}$ and maintained for $3 \mathrm{~d}$ at room temperature to allow polymerization. For $\mathrm{A} \beta_{1-40}$ (Global Peptides, Fort Collins, CO), the peptide was first dissolved in dimethyl sulfoxide to a concentration of $5 \mathrm{~mm}$ and then diluted into PBS to a final concentration of $500 \mu \mathrm{M}$. The diluted peptide solution was allowed to aggregate at $37^{\circ} \mathrm{C}$ for $5 \mathrm{~d}$ in a $5 \% \mathrm{CO}_{2}$-supplemented atmosphere. CECs were treated with $25 \mu \mathrm{M} \mathrm{A} \beta_{25-35}, 25 \mu \mathrm{M} \mathrm{A} \beta_{1-40}$, or 25 $\mu \mathrm{M} \mathrm{C}{ }_{2}$ ceramide (Biomol, Plymouth Meeting, PA) in serum-free growth medium for various time intervals. In some experiments, CECs were treated with okadaic acid (OA), a selective PP2A inhibitor, or 1,2dioleoyl-sn-glycero-3-phosphate (PA), a selective PP1 inhibitor (Upstate Biotechnology, Lake Placid, NY) 1 h before A $\beta$ exposure. For nSMase inhibitor studies, CECs were treated with $1 \mu \mathrm{M}$ 3-O-methylsphingomyelin (3-OMe-SM), a specific nSMase inhibitor, for $2 \mathrm{~h}$ before $25 \mu \mathrm{M} \mathrm{A} \beta_{25-35}$ exposure for $4 \mathrm{~h}$.

APPsw transgenic mice and cerebral microvessel isolation. APPsw mice overexpress human APP695 with the familial Swedish AD mutations at positions 670/671 under control of the prion promoter and were a generous gift from Dr. K. Hsiao-Ashe (Minneapolis, MN). The production, genotyping, and background strain (B6/SJL) of APPsw (Tg2576) mice used in this study have been described previously (Hsiao et al., 1996). Cerebral microvessel isolation used previously described methods with modifications (Pardridge et al., 1985; Zlokovic et al., 1993). Briefly, mice were killed by decapitation under anesthesia. The brains were immediately removed from the skull and immersed in ice-cold buffer A (in mM: $103 \mathrm{NaCl}, 4.7 \mathrm{KCl}, 2.5 \mathrm{CaCl}_{2}, 1.2 \mathrm{KH}_{2} \mathrm{PO}_{4}, 1.2 \mathrm{MgSO}_{4}$, and 15 HEPES, $\mathrm{pH}$ 7.4). The brain was homogenized in a fivefold volume excess of buffer B (103 mm NaCl, $4.7 \mathrm{~mm} \mathrm{KCl}, 2.5 \mathrm{~mm} \mathrm{CaCl}_{2}, 1.2 \mathrm{~mm} \mathrm{KH}_{2} \mathrm{PO}_{4}, 1.2 \mathrm{~mm}$ $\mathrm{MgSO}_{4}, 15 \mathrm{~mm}$ HEPES, $25 \mathrm{~mm} \mathrm{HCO}_{3}, 10 \mathrm{~mm}$ glucose, $1 \mathrm{~mm}$ sodium pyruvate, and $1 \mathrm{~g} / 100 \mathrm{ml}$ dextran, $\mathrm{pH}$ 7.4) with a Teflon homogenizer.
The homogenate was suspended in an equal volume of $25 \%$ BSA and centrifuged at $5800 \times g$ at $4^{\circ} \mathrm{C}$ for $30 \mathrm{~min}$. The pellet was resuspended in $10 \mathrm{ml}$ of buffer B and passed over an $85 \mu \mathrm{m}$ nylon mesh (Tetko, Depu, $\mathrm{NY}$ ). This filtrate was then passed over a $3 \times 4 \mathrm{~cm}$ glass bead column ( $0.45 \mathrm{~mm}$ glass beads) with a $44 \mu \mathrm{m}$ nylon mesh at the bottom and washed with $400 \mathrm{ml}$ of buffer B. Microvessels adhere to the glass beads, whereas contaminants pass unimpeded. Microvessels were recovered by repeated gentle agitation of the glass beads in buffer $\mathrm{B}$. The supernatant containing microvessels was decanted and spun at $500 \times g$ for $5 \mathrm{~min}$, and the final pellet was stored at $-80^{\circ} \mathrm{C}$ until RNA extraction.

Real-time PCR and reverse transcription-PCR. Real-time PCR was used to measure mRNA expression of $\mathrm{BH} 3$-only proteins. Total RNA from the mouse brain microvessel fraction or cultured mouse CECs were isolated with the RNeasy Mini kit (Qiagen, Valencia, CA). Equal amounts of total RNA (600 ng) were reverse transcribed with $1 \mu \mathrm{mol} / \mathrm{L}$ oligo (dT) and 0.5 $\mathrm{mmol} / \mathrm{L}$ dNTPs (Qiagen), $10 \mathrm{U}$ of Rnasin (Promega, Madison, WI), and $4 \mathrm{U}$ of reverse transcriptase (Qiagen) for $1 \mathrm{~h}$ at $37^{\circ} \mathrm{C}$. Ten nanograms of cDNA were subjected to PCR using the ABI Prism 7000 Sequence Detection System and SYBR Green PCR Master Mix (both from Applied Biosystems, Foster City, CA). The primers of the BH3-only genes were designed using Primer Express software (Applied Biosystems) as follows: bim (forward, 5'-CGGATCGGAGACGAGTTCA-3'; reverse, 5' TTCAGCCTCGCGGTAATCA-3'); bid (forward, 5' - GAAGACGAGCTGCAGACAGATG-3'; reverse, $5^{\prime}$ - TGGCTCTATTCTTCCTTGGTTGA-3'); bad (forward, 5' - GCAGGCACTGCAACACAGAT-3'; reverse, 5' - CTCCTTTGCCCAAGTTTCGAT-3'); bmf (forward, 5' TACGCAACAACACCAGCAGAA-3'; reverse, $5^{\prime}$ - CGAGGTTTTGAAGGAAGAGGAA- $3^{\prime}$ ); $d p 5$ (forward, $5^{\prime}$ - TGGAGGAAGCTGGTTCCTGTT-3'; reverse, $5^{\prime}$ - CAGCTCTTTACAATTCTGCTTCCTT-3'); $c y$ clophilin (forward, 5' -CGCTTCCCAGATGAGAACTTCA-3'; reverse, 5ACTGTGGTTATGAAGAACTGTGA-3'). A standard amplification program was used $\left(1 \mathrm{cycle}\right.$ of $50^{\circ} \mathrm{C}$ for $2 \mathrm{~min}, 1$ cycle of $95^{\circ} \mathrm{C}$ for $10 \mathrm{~min}$, 45 cycles of $95^{\circ} \mathrm{C}$ for $15 \mathrm{~s}$, and $60^{\circ} \mathrm{C}$ for $1 \mathrm{~min}$ ). All quantifications were normalized to cyclophilin to account for variability in the initial concentration and quality of total RNA and in the conversion efficiency of the reverse transcription (RT) reaction. The expression of bim mRNA was also detected by conventional RT-PCR (Yin et al., 2002a). cDNA was amplified in $0.2 \mathrm{mmol} / \mathrm{L}$ dNTPs, $1 \mu \mathrm{mol} / \mathrm{L}$ of each primer, $1.5 \mathrm{mmol} / \mathrm{L}$ $\mathrm{MgCl}_{2}$, and $2.5 \mathrm{U}$ of Taq polymerase (Roche, Indianapolis, IN). PCR was performed for 26 cycles alternating between $95^{\circ} \mathrm{C}$ for $20 \mathrm{~s}, 53^{\circ} \mathrm{C}$ for $30 \mathrm{~s}$, followed by extension at $72^{\circ} \mathrm{C}$ for $1 \mathrm{~min}$. Primers were designed based on the mouse bim sequences (forward, $5^{\prime}$-ctgagtgtgacagagaaggtg- $3^{\prime}$; reverse, $5^{\prime}$-gtggtcttcagcctcgcggt- $\left.3^{\prime}\right)$. The amplified products were analyzed on a $1 \%$ agarose gel. The relative mRNA level of bim was normalized to endogenous cyclophilin mRNA for each sample. The RT-PCR was conducted within the linear ranges of PCR cycles and RNA input. The PCR experiments were repeated at least three times.

Protein phosphatase activity assay. An immunoprecipitation phosphatase assay kit (Upstate Biotechnology) was used to measure phosphate release as an index of phosphatase activity. Total cellular proteins from $\mathrm{A} \beta$-treated mouse CECs or cerebral microvessels in APPsw transgenic mice were extracted in radioimmunoprecipitation assay buffer. Protein concentrations were determined using a Bio-Rad (Hercules, CA) bicinchoninic acid assay. Assays were run in 96-well plates according to the manufacturer's instructions. Briefly, $50-100 \mu \mathrm{g}$ of cellular proteins was immunoprecipitated with a mouse anti-PP2A catalytic subunit antibody ( $2 \mu \mathrm{g} / \mathrm{ml}$; Upstate Biotechnology) or a mouse anti-PP1 antibody $(2 \mu \mathrm{g} /$ $\mathrm{ml}$; Santa Cruz Biotechnology, Santa Cruz, CA) and incubated with 4.5 $\mu l$ of the substrate, phosphoprotein (amino acid sequence: KRpTIRR) at a concentration of $175 \mu \mathrm{M}$, and protein phosphatase assay buffer $(20 \mathrm{mM}$ 4-morpholinepropanesulfonic acid, pH 7.5, 60 mM 2-mercaptoethanol, $0.1 \mathrm{M} \mathrm{NaCl}$, and $0.1 \mathrm{mg} / \mathrm{ml}$ serum albumin) in a final volume of $25 \mu \mathrm{l}$. Reactions were started with the addition of the phosphoprotein substrate and conducted for $10 \mathrm{~min}$ at room temperature. Reactions were terminated by the addition of $100 \mu \mathrm{l}$ of malachite green solution, and color was developed for $15 \mathrm{~min}$ before reading the plate at $650 \mathrm{~nm}$.

Electrophoretic mobility shift assay. Electrophoretic mobility shift assay (EMSA) to assess DNA binding activity has been described in detail previously (Yin et al., 2002a,b). The following FKHRL1 consensus oligo- 
A

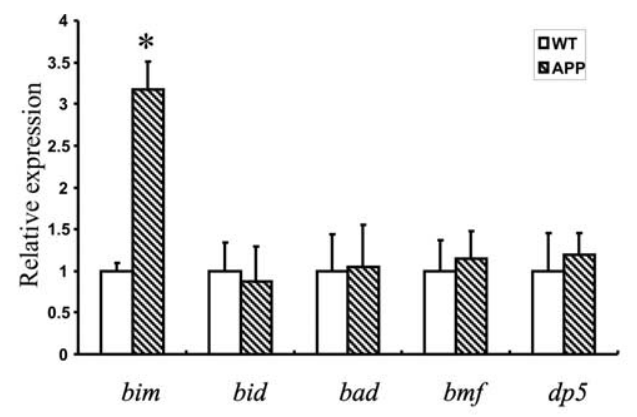

B

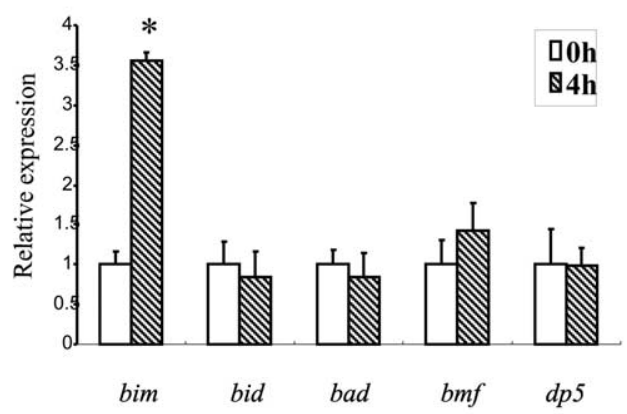

C

0h $\quad 1 \mathrm{~h} \quad 2 \mathrm{~h} \quad 4 \mathrm{~h} \quad 8 \mathrm{~h} \quad 24 \mathrm{~h} \quad 48 \mathrm{~h}$

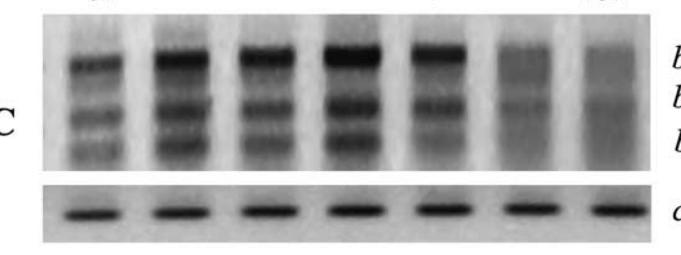

bimEL

bimL

bimS

cyclophilin

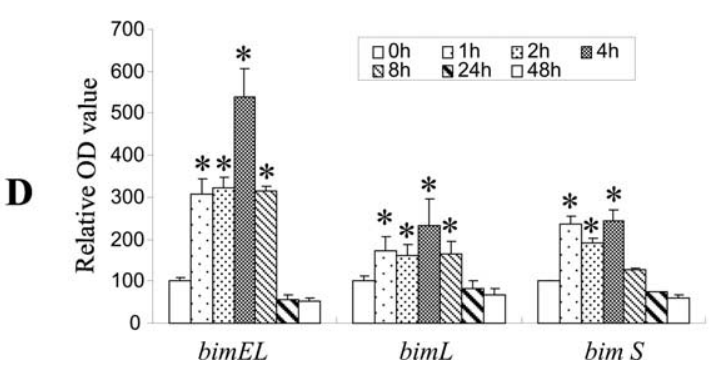

Figure 1. bim expression was selectively increased in amyloid-laden vessels in vivo and in $A \beta$ treated CECs in vitro. $\boldsymbol{A}$, Total RNA from the cerebral microvessel fraction of 18-month-old APPsw transgenic or age-matched wild-type (WT) mice was analyzed by quantitative real-timePCR to assess expression of BH3-only genes. Only the mRNA level of bim was increased in amyloid-laden vessels of APPsw transgenic mice compared with the wild-type controls ( $n=3$ per group). Data are expressed as mean \pm SD. ${ }^{*} p<0.05$, significant difference from wild type. $B$, CECs treated with $25 \mu \mathrm{mA} \beta_{25-35}$ at 0 or $4 \mathrm{~h}$ were isolated for extraction of total RNA for quantitative real-time PCR. $A \beta$ exposure for $4 \mathrm{~h}$ significantly increased the mRNA level of bim but not other BH3-only genes. Data are expressed as mean $\pm S D^{*} p<0.05$, significant difference from $0 \mathrm{~h}$. C, Expression of the BH3-only genes in CECS treated with $25 \mu \mathrm{m} \mathrm{A} \beta_{25-35}$ for the indicated times were analyzed by RT-PCR. A $\beta$ increased the expression of three isoforms of bim ( $\mathrm{bimEL}$, bimL, bimS) as early as $1 \mathrm{~h}$ after exposure. Upregulation of these three isoforms was sustained for $8 \mathrm{~h}$ before declining to basal levels. Levels of cyclophilin mRNA were used as an internal control. The data shown are representative of three separate experiments with similar results. D, Quantitative analysis of three PCR images (normalized to cyclophilin) using the NIH Image Analysis System graphically illustrates a time-dependent increase in the three isoforms of bim after $A \beta$ treatment. Data (relative optical density) are expressed as mean $\pm S D .{ }^{*} p<0.05$ versus the $0 \mathrm{~h}$ group.

nucleotides were used, $5^{\prime}$-AATAGATCTTAAATAAATAGATCTTTA-3' and $5^{\prime}$ - TAAAGATCTATTTATTTAAGATCTATT-3' (Brunet et al., 1999), and labeled with $\gamma^{32} \mathrm{P}$-ATP. The binding reaction was performed in a final volume of $20 \mu \mathrm{l}$ of binding buffer containing $0.0175 \mathrm{pmol}$ of labeled probe ( $>10,000 \mathrm{cpm}), 20 \mu \mathrm{g}$ of nuclear proteins, and $1 \mu \mathrm{g}$ of poly dIdC. After incubation for $20 \mathrm{~min}$ at room temperature, the mixture was subjected to electrophoresis on a nondenaturing $6 \%$ polyacrylamide gel at $180 \mathrm{~V}$ for $2 \mathrm{~h}$ under low ionic strength conditions. The gel was dried and subjected to autoradiography. For supershift assays, samples were incubated with anti-FKHRL1 (1:100; Upstate Biotechnology) or antiBad (1:100; Cell Signaling, Beverly, MA) antibody for $1 \mathrm{~h}$ before the addition of the $\gamma_{-}{ }^{32} \mathrm{P}$-ATP FKHRL1 oligonucleotide probe. The specificity of FKHRL1 DNA binding activity was also demonstrated by the complete inhibition of FKHRL1 binding in the presence of a 100-fold molar excess of the cold FKHRL1 oligonucleotide.

Western blot analysis. Cytoplasmic and nuclear proteins were isolated from CECs after treatment as reported previously (Xu et al., 2001; Yin et al., $2002 \mathrm{~b}$ ). Twenty to $40 \mu \mathrm{g}$ of proteins from each sample were analyzed by $10-15 \%$ SDS-PAGE gel and transferred to polyvinylidene difluoride (PVDF) membranes. The blot was incubated with various primary antibodies including rabbit anti-phospho-Akt (Thr308) (1;1000; Cell Signaling), rabbit anti-phospho-Akt (Ser473) (1:1000; Cell Signaling), rabbit antiphospho-FKHRL1 (Ser253) (1;500; Upstate Biotechnology), rabbit antiphospho-FKHRL1 (Thr32) (1:1000; Upstate Biotechnology), rabbit anti-phospho-ERK1/2 (1:1000; Cell Signaling), mouse anti-phospho-JNK (1:1000; Cell Signaling), mouse anti-PP2A catalytic subunit (1:1000; Upstate Biotechnology), and mouse anti-actin (1:200; Santa Cruz Biotechnology). The membranes were then incubated with the appropriate secondary antibody (1:5000; anti-rabbit or anti-mouse IgG conjugated with alkaline phosphatase; Promega) at room temperature for $1 \mathrm{~h}$. The color reaction was developed using the AP Blot System (Promega) according to the manufacturer's instructions.

Construction of retrovirus-mediated RNA interference of PP2A in CECs. A retrovirus vector carrying small interfering RNAs (siRNAs) targeting the mouse PP2A gene was prepared by the BD Knockout RNAi System (BD Biosciences Clontech, Palo Alto, CA). The PAGE-purified complementary oligonucleotide pair for the hairpin siRNA was synthesized to target the coding region of mouse PP2A catalytic subunit mRNA as follows: $5^{\prime}$-gatccGTGTGTGACTTGCTGTGGTCTTCAAGAGAGACCACAGCAAGTCACACATTTTTTg-3' ${ }^{\prime}$, 5' -aattcAAAAAATGTGTGACTTGCTGTGGTCTCTCTTGAAGACCACAGCAAGTCACACACg- $3^{\prime}$. A complementary pair of oligonucleotides for a sense-only control RNA was also designed using the following sequences: $5^{\prime}$ gatccGTGTGTGACTTGCTGTGGTCTTCAAGAGATTTTTTg-3'， 5' aattcAAAAAATCTCTTGAAGACCACAGCAAGTCACACACg-3'. These oligonucleotide pairs containing BamHI and EcoRI overhangs were annealed and ligated to a linearized RNAi-Ready pSIREN-RetroQZsGreen vector digested with BamHI and EcoRI (BD Biosciences Clontech). The RNAi-Ready pSIREN-RetroQ-ZsGreen vector is a selfinactivating retroviral expression vector designed to express a small hairpin RNA using the human U6 promoter. The resultant constructs were amplified, purified, and sequenced. For production of high-titer retrovirus vectors expressing PP2A small hairpin RNA, EcoPack-293 cell lines (BD Biosciences Clontech) were plated at $\sim 50-75 \%$ confluence, and the recombinant vectors were transfected into EcoPack- 293 cells by a modified calcium phosphate method. After incubation at $32^{\circ} \mathrm{C}$ for $2 \mathrm{~d}$, the supernatant fraction containing the viral vector was collected and passed through a $0.45 \mu \mathrm{m}$ filter. CECs were infected with the retroviral vector in the presence of Polybrene $(5-10 \mu \mathrm{g} / \mathrm{ml})$ and incubated for $3 \mathrm{~h}$. The supernatant fraction containing the retroviral vector was removed and replaced with normal growth medium. Cells grown for $48-72 \mathrm{~h}$ were assessed by fluorescence microscopy. The ZsGreen fluorescent marker yields a bright green fluorescence, permitting direct monitoring of the delivery efficiency in CECs. Infected populations exhibiting between 60 and $75 \%$ green fluorescent cells were used for additional experimentation.

Construction of adenovirus-mediated overexpression of Akt in CECs. Akt cDNAs, including a nonfunctional mutant and an overexpressing construct, were obtained from pCMV-HA-K179m-Akt (mutant Akt) and pCMV-myr-HA-Akt by PCR amplification (Franke et al., 1995). The PCR products were cloned into a pGEM-T Easy vector (Promega), isolated by NotI-NotI digestion, and subcloned into a p-Shuttle vector (BD Biosciences Clontech). The p-Shuttle vectors were subcloned into the Adeno-X expression system (BD Biosciences Clontech) using PI-SceI 


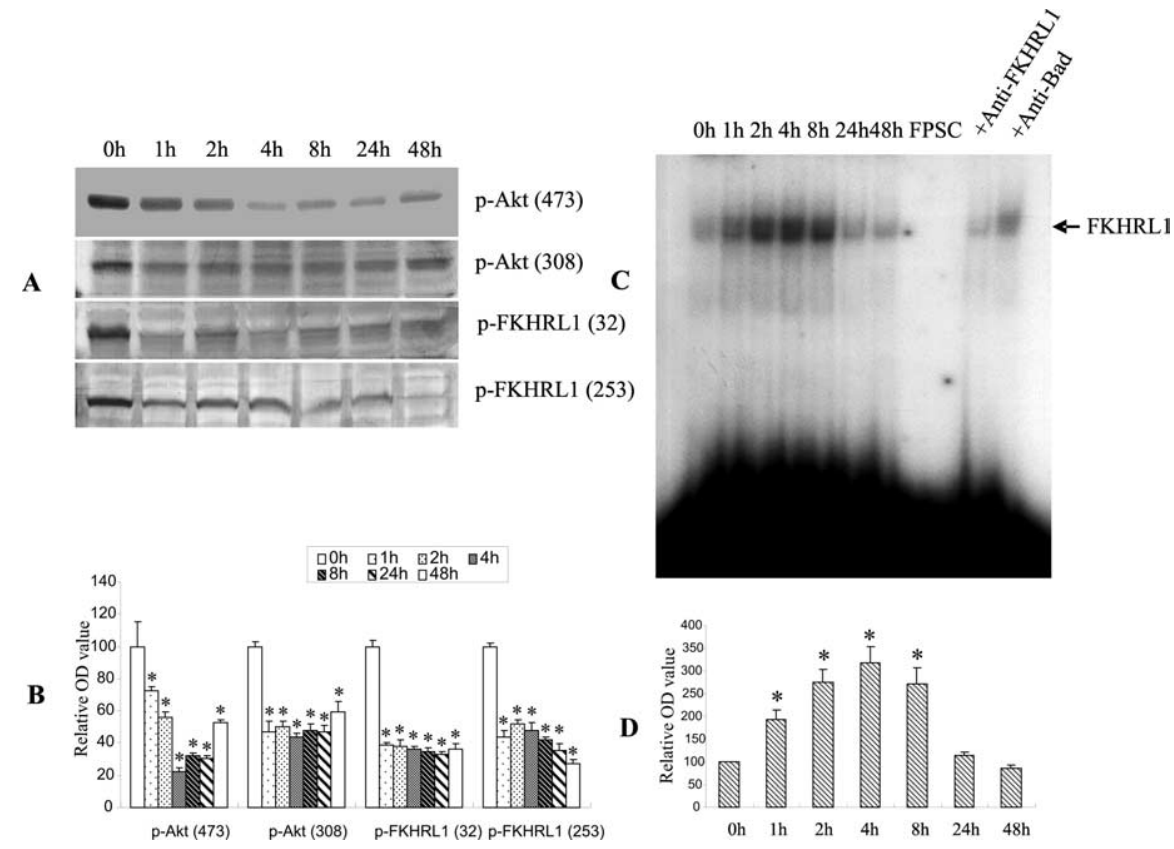

Figure 2. $\mathrm{A} \beta$ dephosphorylated Akt resulting in an increase in FKHRL1 DNA binding activity. $\boldsymbol{A}, \boldsymbol{B}, \mathrm{CECS}$ treated with $25 \mu \mathrm{M}$ $A \beta_{25-35}$ for the indicated times were analyzed by immunoblotting using anti-p-Akt (Thr308 and Ser473) and anti-p-FKHRL1 (Thr32 and Ser253) antibodies. A decrease in p-Akt and p-FKHRL1 levels was evident at both sites within $1 \mathrm{~h}$ and persisted for at least $48 \mathrm{~h}$ after exposure. C, D, EMSA demonstrated a time-dependent increase in FKHRL1 binding activity after $A \beta_{25-35}$ treatment in CECs, increasing $1 \mathrm{~h}$ after exposure and returning to the basal level by $24 \mathrm{~h}$. Note the low basal level of FKHRL1 binding activity in cultures unexposed to $A \beta_{25-35}(0 \mathrm{~h})$. The specificity of FKHRL1 DNA binding activity was confirmed by the complete inhibition of FKHRL1 binding in the presence of a 100-fold molar excess of cold FKHRL1 oligonucleotide (SC) or in the absence of nuclear protein (FP). Suppression of FKHRL1 binding activity by an anti-FKHRL1 antibody, but not a nonspecific anti-Bad antibody (compare with the $2 \mathrm{~h}$ lane), also supports the specificity of the FKHRL1 EMSA. The data shown in $\boldsymbol{A}$ and $\boldsymbol{C}$ are representative from three separate experiments with similar results. The relative optical density in Figure $\boldsymbol{B}$ and $\boldsymbol{D}$ is expressed as mean \pm SD. ${ }^{*} p<$ 0.05 versus the $0 \mathrm{~h}$ group.

and I-CeuI. The resultant Adeno-X-containing Akt and mutant Akt were transformed into Escherichia coli for amplification, purified, and analyzed by PCR. Recombinant Adeno-X viral DNAs were confirmed and amplified. The recombinant Adeno-X DNAs were linearized by digestion with PacI for transfection. For production of high-titer adenoviral vector expressing Akt, $10 \mu \mathrm{g}$ of recombinant Adeno-X DNA vector was transfected into HEK 293 cells. The adenoviral vector was collected from the cells 10-14 d after transfection and amplified for another 10-14 d to generate high-titer stocks. To concentrate adenovirus, we used a $\mathrm{BD}$ Adeno-X virus purification kit (BD Biosciences Clontech), and titers were determined with Adeno-X rapid titer kits (BD Biosciences Clontech). Normally, we obtained titers in the range of $10^{10}$ to $10^{12} \mathrm{ifu} / \mathrm{ml}$. CECs were infected with the adenoviral vectors at a titer of $10^{10} \mathrm{ifu} / \mathrm{ml}$ for $48 \mathrm{~h}$, and the culture medium was changed. Infected populations exhibiting between 85 and 95\% green fluorescent cells were used for additional experimentation.

Coimmunoprecipitation. Coimmunoprecipitation was conducted as described previously (Yin et al., 2002b). A $\beta$-treated CECs were homogenized in a lysis buffer ( $1 \%$ Triton X-100, $150 \mathrm{~mm} \mathrm{NaCl}, 10 \mathrm{~mm}$ Tris, $\mathrm{pH}$ 7.4, 1 mm EDTA, 1 mM EGTA, pH 8.0, 0.2 mm sodium ortho-vanadate, $0.5 \% \mathrm{NP}-40,0.2 \mathrm{~mm}$ PMSF, $4 \mu \mathrm{g} / \mathrm{ml}$ pepstatin, $4 \mu \mathrm{g} / \mathrm{ml}$ leupeptin, and 5 $\mu \mathrm{g} / \mathrm{ml}$ aprotinin), and the supernatant was incubated with a rabbit antiAkt antibody ( $2 \mu \mathrm{g} / \mathrm{ml}$; Cell Signaling) as described above. Protein G-Sepharose 4 fast flow (Amersham Biosciences, Uppsala, Sweden) was added to the antigen-antibody mixture and incubated with gentle agitation for 1-2 h. The immunoprecipitate was washed with the same lysis buffer, resuspended in $6 \times$ SDS loading buffer, separated in a SDSPAGE gel, transferred to the PVDF membrane, and analyzed by Western blotting with a goat anti-PP2A-A $\alpha$, goat anti-PP2A-B $\alpha / \beta / \gamma$, goat anti-PP2A-B56 $\alpha$, or goat anti-PP2A-C $\alpha / \beta$ antibody (1:200; Santa Cruz Biotechnology).
Assessment of CEC death. CEC survival or death was assessed by the 3-(4,5-dimethylthiazol-2-yl)2,5-diphenyl-tetrazolium bromide (MTT) and lactate dehydrogenase (LDH) assays as described previously (Yin et al., 2002b)

Quantitative and statistical analysis. Quantitative analysis of selected bands in Western blots, PCR images, and EMSA gels was performed using the NIH Image Analysis System.

Quantitative data were expressed as mean \pm SD based on at least three separate experiments of triplicate samples. Differences among groups were statistically analyzed by one-way ANOVA, followed by Bonferroni's post hoc $t$ test. Comparison between two experimental groups was based on the two-tailed $t$ test. $p<0.05$ was considered significant.

\section{Results}

bim mRNA expression was upregulated in amyloid-laden vessels in vivo and in $\mathrm{A} \beta$-treated CECs in vitro

In a previous study, we have shown that $\mathrm{A} \beta$ induced Bim expression, leading to Smac release from mitochondria into $\mathrm{cy}$ tosol to bind XIAP, a member of the IAP (inhibitor of apoptosis protein) family. This series of events resulted in CEC apoptosis (Yin et al., 2002b). Bim belongs to the BH3-only subgroup of the Bcl-2 family of apoptosis regulators (Kelekar and Thompson, 1998; Huang and Strasser, 2000). To examine the potential role of $\mathrm{BH} 3$-only regulators in cerebrovascular degeneration in CAA, we measured the mRNA from various $\mathrm{BH} 3$-only genes including bim, bid, bad, bmf, and $d p 5$ in cerebral microvessels isolated from APPsw (Tg2576) mice at age 18 months when CAA is fully manifested (Fryer et al., 2003; Lee et al., 2003). Compared with age-matched wild-type controls, bim mRNA was selectively elevated based on real-time PCR (Fig. $1 A$ ), suggesting that the induction of bim may play an important role in cerebrovascular degeneration in this animal model of CAA. We also examined the expression of $\mathrm{BH} 3$-only genes in CECs treated with $\mathrm{A} \beta$ for $4 \mathrm{~h}$. bim mRNA was also selectively induced (Fig. $1 B$ ). A time course study revealed that $\mathrm{A} \beta$ rapidly induced all three isoforms of $\operatorname{bim}(\operatorname{bim} E L, \operatorname{bimL}, \operatorname{bimS}$ ) in CECs, as early as $1 \mathrm{~h}$ after exposure; this induction was transient, because very low levels of the bim isoforms were detected beyond $24 \mathrm{~h}$ (Fig. 1C,D).

\section{A $\boldsymbol{\beta}$ dephosphorylated Akt and increased FKHRL1 binding activity}

FKHRL1, a member of the forkhead family of transcription factors (Burgering and Kops, 2002; Gilley et al., 2003), was recently shown to transactivate bim in apoptotic lymphocytes in response to cytokine withdrawal (Dijkers et al., 2000). Furthermore, overexpression of a constitutively active mutant of FKHRL1 was sufficient to increase bim expression in B-cells (Dijkers et al., 2000). The action of forkhead family members is negatively regulated by the phosphorylation of the serine and threonine residues. FKHRL1 has been identified as a principal substrate of Akt in neurons (Brunet et al., 1999; Zheng et al., 2000). Therefore, we first examined the phosphorylation status of Akt and FKHRL1 in mouse CECs after $A \beta$ treatment using immunoblotting with phospho-site-specific antibodies. Exposure of CECs to A $\beta$ (25 
$\mu \mathrm{M})$ resulted in a substantial decrease in the levels of phosphoAkt at both Ser 473 and Thr 308, as early as $1 \mathrm{~h}$ after treatment, and persisted throughout the $48 \mathrm{~h}$ period of exposure (Fig. $2 \mathrm{~A}$ ). In parallel with this decreased phosphorylation of Akt, a marked decline in phospho-FKHRL1 levels on Ser 253 and Thr32 in the cytoplasmic fraction was observed (Fig. $2 A, B$ ), suggesting that $\mathrm{A} \beta$ exposure resulted in a net dephosphorylation of Akt and the subsequent reduction in FKHRL1 phosphorylation.

Phosphorylation of FKHRL1 by Akt leads to its sequestration by the 14-3-3 protein, preventing its translocation into the nucleus to act as a pro-apoptotic transcription factor (Brunet et al., 1999). We next examined whether FKHRL1 dephosphorylation enhanced its specific binding to the cognate sequences in the promoter region of bim in A $\beta$-treated CECs using EMSA. As illustrated in Figure 2, $C$ and $D, \mathrm{~A} \beta$ treatment increased FKHRL1 DNA binding activity in a time-dependent manner, starting as early as $1 \mathrm{~h}$ and persisting for at least $8 \mathrm{~h}$ after $\mathrm{A} \beta$ exposure. A low basal level of FKHRL1 binding activity was noted in CECs without $A \beta$ treatment. Preincubation of the nuclear extract with antiFKHRL1 antibody, but not anti-Bad antibody, reduced FKHRL1 DNA binding activity (Fig. 2C). The addition of excess unlabeled FKHRL1 oligonucleotides abolished the observed DNA-protein complex. These results demonstrated the specificity of FKHRL1 DNA binding activity in the present study.

\section{Viral vector-mediated gene transfer to overexpress Akt attenuated $\mathrm{A} \boldsymbol{\beta}$-induced dephosphorylation of FKHRL1 and bim induction}

To assess the direct role of Akt in the regulation of FKHRL1 activity and bim expression in CECs, we infected cells with an adenoviral vector to overexpress Akt in an attempt to increase phospho-Akt levels in CECs. CECs exhibited an infection efficiency of $70-80 \%$, and no significant cell death or proliferation was observed in control cultures (data not shown).

As shown in Figure 3, $A$ and $B$, adenovirus-mediated gene transfer overexpressing Akt reduced $A \beta$-induced FKHRL1 binding activity and subsequent expression of bim mRNA, whereas a nonfunctional mutant (Aktm) had no effect. Results from these experiments support the causal role of Akt in regulating $\mathrm{A} \beta$ induced FKHRL1 transactivation of bim expression.

\section{$\mathrm{A} \boldsymbol{\beta}$ increased protein phosphatase activity in cultured CECs via nSMase activation and ceramide synthesis}

The regulation of phosphorylated protein is balanced by the activity of kinases and phosphatases. A $\beta$ dephosphorylation of Akt and FKHRL1 raises the possibility that phosphatases may be activated in $\mathrm{A} \beta$-induced $\mathrm{CEC}$ apoptosis. In light of our previous finding that $\mathrm{A} \beta$ promoted the generation of ceramide via nSMase activation (Lee et al., 2004; Yang et al., 2004), we examined the activities of two protein phosphatases, PP1 and PP2A, known to be activated by ceramide (Dobrowsky and Hannun, 1993; Dobrowsky et al., 1993; Law and Rossie, 1995; Chalfant et al., 1999). These two serine phosphatases regulate the activities of several major protein kinase signaling pathways in a variety of cell systems, including the phosphatidylinositol 3'-kinase/Akt signaling pathway (Millward et al., 1999; Silverstein et al., 2002). CECs treated with both $\mathrm{A} \beta_{25-35}$ (Fig. $4 A$ ) and $\mathrm{A} \beta_{1-40}$ (Fig. $4 B$ ) significantly increased PP2A activity as early as $1 \mathrm{~h}$ after exposure and persisted for $24 \mathrm{~h}$. A $\beta$ peptides also induced a modest but nonsignificant increase in PP1 activity in a similar manner (Fig. $4 A, B)$. We further examined the effect of the ceramide analog $\mathrm{C} 2$ ceramide on the activities of PP2A and PP1 in CECs. Similar to

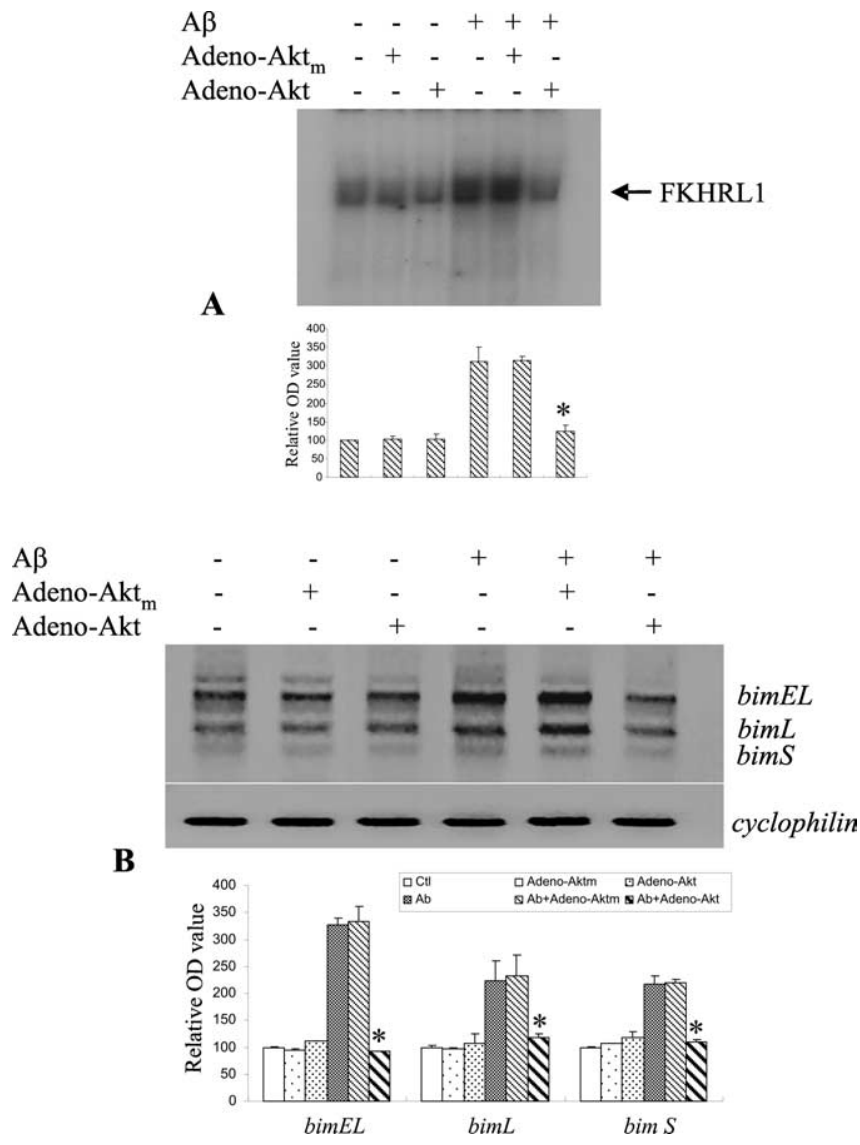

Figure 3. Adenoviral gene transfer overexpressing Akt reduced $A \beta$ activation of FKHRL1 and subsequent bim transactivation. $A$, Adenoviral gene transfer to overexpress Akt in CECs reduced FKHRL1 binding activity, whereas an inactive mutant (Akt $\left.t_{m}\right)$ had no effect. $\boldsymbol{B}$, Adeno-Aktinfected CECs showed a decrease in $A \beta$-induced upregulation of the three isoforms of bim. Adeno-Akt $t_{m}$-infected CECs had approximately the same level of FKHRL1 binding activity as the noninfectced cells. Quantitative analysis of three sets of data is shown in the bottom panel in $\boldsymbol{A}$ and $\boldsymbol{B}$, respectively, with mean $\pm S D .{ }^{*} p<0.05$ versus the $A \beta$ or $A \beta / A d e n 0-A k t_{m}$ group.

$\mathrm{A} \beta$ treatment, $25 \mu \mathrm{M} \mathrm{C} 2$ ceramide increased PP2A activity as early as $0.5 \mathrm{~h}$ after exposure but had little effect on PP1 (Fig. 4C).

To determine whether $\mathrm{A} \beta$-induced activation of PP2A was mediated via nSMase, we blocked the activity of this ceramidesynthesizing enzyme using a selective nSMase inhibitor, 3-OMeSM. 3-OMe-SM has been shown previously to block $\mathrm{A} \beta$ activation of nSMase and $\mathrm{A} \beta$ stimulation of ceramide synthesis (Lee et al., 2004; Yang et al., 2004). 3-OMe-SM blocked A $\beta$-induced increase in PP2A activity (Fig. $4 D$ ), suggesting that $\mathrm{A} \beta$ activation of nSMase is causally related to ceramide generation and PP2A activation.

To further explore the potential involvement of CAPPs in cerebrovascular degeneration in CAA, we measured protein phosphatase activity in cerebral microvessels isolated from 18month-old APPsw mice. PP2A, but not PP1, activity was significantly increased compared with age-matched wild-type animals (Fig. $4 E$ ), implying that the induction of PP2A may also play a regulatory role in cerebrovascular degeneration in CAA.

PP2A, but not PP1, dephosphorylated Akt, resulting in subsequent $\mathrm{bim}$ induction and CEC death

To determine whether PP2A regulates Akt activity after $\mathrm{A} \beta$ treatment in CECs, we blocked PP2A activity applying both pharmacological and genetic strategies. OA is a selective inhibitor of PP2A at low concentrations $(0.1-10 \mathrm{nM})$ but inhibits PP1 at 

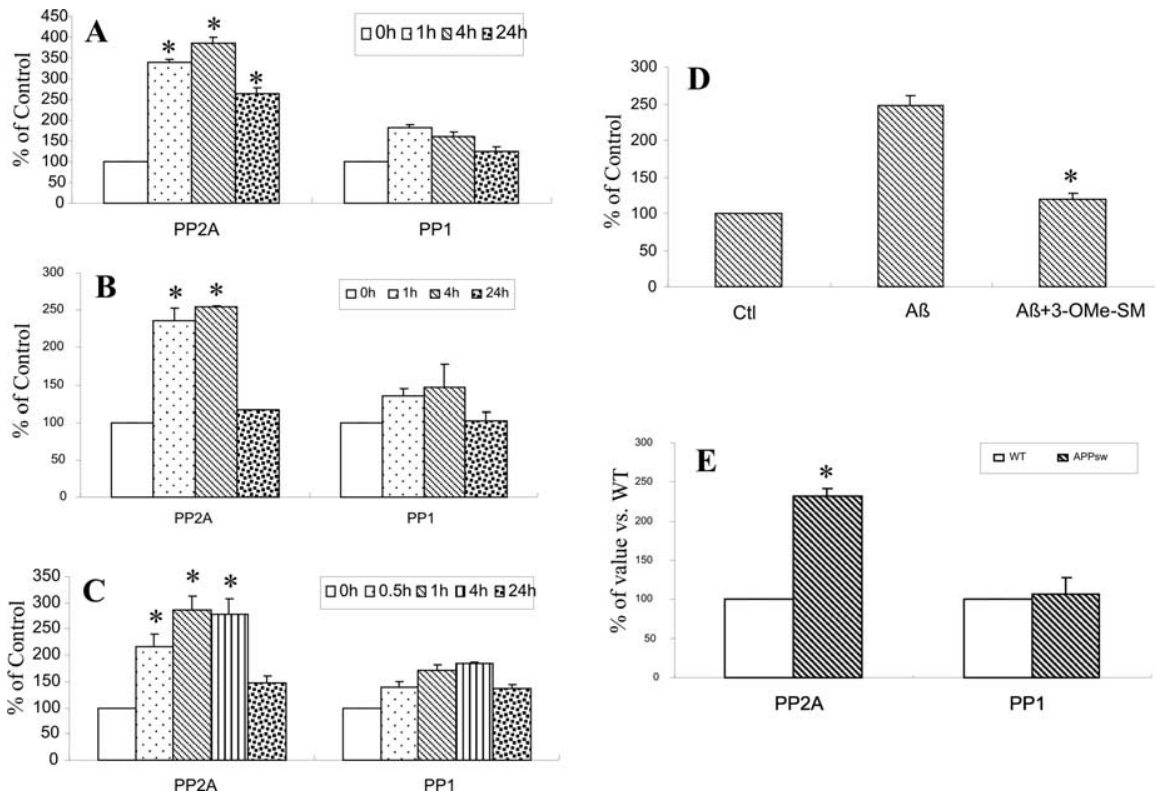

Figure 4. $A \beta$ increased PP2A activity via nSMase activation and ceramide generation. $\boldsymbol{A}, \boldsymbol{B}, \mathrm{CEC}$ s were treated with $25 \mu \mathrm{M}$ $A \beta_{25-35}(A)$ or $A \beta_{1-40}(B)$ for the indicated times, and PP2A activity was determined. $A \beta$ peptides increased PP2A activity in CECs in a time-dependent manner. $C, C 2$ ceramide treatment at a concentration of $25 \mu \mathrm{m}$ also increased PP2A activity in a similar manner. $\boldsymbol{A}-\boldsymbol{C}$, However, $A \beta$ and $C 2$ ceramide increased PP1 activity to a much lesser extent. $\boldsymbol{D}$, Pretreatment with 3-0Me-SM, a specific nSMase inhibitor at a concentration of $1 \mu \mathrm{M}$, for $2 \mathrm{~h}$ before $25 \mu \mathrm{MA} \beta_{25-35}$ exposure for $4 \mathrm{~h}$ prevented $A \beta$ activation of PP2A. $\boldsymbol{E}$, Total proteins from the cerebral microvessel in 18-month-old APPsw transgenic or age-matched wild-type (WT) mice were analyzed to assess protein phosphatase activity. PP2A but not PP1 activity was increased in amyloid-laden vessels of APPsW transgenic mice in compared with the wild-type controls ( $n=3$ per group). The data shown are mean \pm SD of three separate experiments in triplicate. ${ }^{*} p<0.05$, significant difference from the $0 \mathrm{~h}(\boldsymbol{A}-\boldsymbol{C}), \mathrm{A} \beta$-treated $(\boldsymbol{D})$, or WT (E) group.

$\mathrm{A} \beta$ (Fig. 5D). These results suggest that the effect of PP2A on Akt/FKHRL1/Bim cascade and subsequent CEC death is independent of the JNK/Bim signaling pathway.

To further confirm the involvement of $\mathrm{PP} 2 \mathrm{~A}$ in regulating $\mathrm{A} \beta$-induced transactivation of bim mRNA, we used a retroviral system for delivery of siRNA into CECs. We generated retroviral vectors expressing hairpin siRNA of the PP2A catalytic unit (pS-PP2A) or the corresponding nonfunctional sense siRNA control (pS-PP2Ac). Successful delivery of both recombinant retroviral vectors into CECs was confirmed by fluorescence microscopy, which revealed abundant cytoplasmic staining of the virally expressed ZsGreen (Fig. 6A). CECs were infected with the retroviral vectors for $48 \mathrm{~h}$ before $\mathrm{A} \beta$ exposure. PP2A mRNA levels (Fig. $6 B$ ), protein expression (Fig. 6C), and activity (Fig. 6D) were significantly repressed by treatment with $\mathrm{pS}$ PP2A for $48 \mathrm{~h}$, whereas the nonfunctional sense siRNA control (pS-PP2Ac) had no effect (Fig. 6B-D). Retroviral siRNA vectors did not alter levels of cyclophilin mRNA and actin protein, suggesting specificity of the knock-down strategy. PP2A siRNA gene transfer effectively attenuated $\mathrm{A} \beta$-induced Akt/FKHRL1 dephosphorylation (Fig. 6E), bim mRNA expression

much higher concentrations (Cohen, 1989; Cohen and Cohen, 1989; Dobrowsky and Hannun, 1992). Treatment with OA at the concentration of $0.1-100 \mathrm{nM}$ resulted in a dose-dependent increase in the levels of phospho-Akt at both Ser 473 and Thr 308 in CECs after $A \beta$ exposure as demonstrated by Western blot analysis (Fig. 5A). In parallel with this increase, a marked increase in phospho-FKHRL1 level was observed (Fig. 5A). This OAinduced increase in phospho-Akt/FKHRL1 level was associated with a dose-dependent inhibition of $\mathrm{A} \beta$-induced activation of bim mRNA expression (Fig. 5B) and in turn resulted in an attenuation of $A \beta$-induced $C E C$ death (Fig. $5 C$ ). Because OA at higher doses ( $\geq 100 \mathrm{nM}$ ) may have inhibitory effects on both PP2A and PP1, we used PA, a selective inhibitor of PP1 (Kishikawa et al., 1999), to confirm that PP2A was the pivotal regulator of bim mRNA expression. Treatment with PA at two doses (100 and 500 $\mathrm{nM}$ ) resulted in no change in the levels of phospho-Akt and phospho-FKHRL1, as assessed by immunoblotting (Fig. 5D). This is in contrast to the findings with $\mathrm{OA}$, a selective inhibitor of PP2A, at low concentrations (Fig. 5A). Furthermore, PA treatment did not have any effect on $\mathrm{A} \beta$-induced bim mRNA expression (Fig. 5E) and cell death in CECs (Fig. 5F).

In previous studies, we found that the JNK/AP1/Bim signaling pathway is activated in CECs after $\mathrm{A} \beta$ exposure (Yin et al., $2002 b)$. To determine whether the effect of PP2A was mediated via the mitogen-activated protein kinase (MAPK) pathways, we examined the effect of PP2A inhibition on the expression of extracellular signal-related kinase (ERK) and c-Jun N-terminal kinase (JNK), in CECs after $A \beta$ exposure. OA had no effect on the levels of phospho-ERK and phospho-JNK after $A \beta$ treatment (Fig. 5A). Furthermore, inhibition of PP1 with PA also had no effect on phospho-ERK or phospho-JNK in CECs treated with
(Fig. 6F), and subsequent CEC death (Fig. 6G,H), whereas pSPP2Ac had none of these effects. These results provide further support for the contention that $\mathrm{PP} 2 \mathrm{~A}$ can actively regulate $\mathrm{A} \beta$ induced bim expression and CEC apoptosis via the Akt/FKHRL1 signaling pathway.

\section{$\mathrm{A} \boldsymbol{\beta}$ induced interaction between PP2A and Akt}

If PP2A directly dephosphorylates Akt, one might expect a physical interaction between these two enzymes after $\mathrm{A} \beta$ exposure. Indeed, a similar interaction was observed between PP2A and the stress-related kinase, JNK (Shanley et al., 2001). To test this hypothesis, lysates from CECs with and without $\mathrm{A} \beta$ treatment were immunoprecipitated with anti-Akt antibodies and examined for the presence of a structural (PP2A A $\alpha$ ) or regulatory (PP2A $\mathrm{B} \alpha \beta \gamma, \mathrm{B} 56 \alpha, \mathrm{C} \alpha \beta)$ subunits of PP2A by immunoblotting. Levels of PP2A subunits were generally unchanged by $\mathrm{A} \beta$ treatment (Fig. $7 A, B$ ). As illustrated in Figure 7, $C$ and $D$, the structural subunit PP2A A $\alpha$ and the regulatory subunit PP2A C $\alpha \beta$ exhibited a specific interaction in the anti-Akt-immunoprecipitated product (Fig. $7 C, D$ ), suggesting that these 2 PP2A subunits had increased physical association with Akt after $A \beta$ exposure.

\section{Discussion}

$\mathrm{A} \beta$ has been implicated in neuronal and vascular degeneration in patients with $\mathrm{AD}$ and $\mathrm{CAA}$. Increasing evidence suggests that $\mathrm{A} \beta$ induces CEC death via apoptosis (Blanc et al., 1997; Suo et al., 1997; Xu et al., 2001; Yin et al., 2002b). We have reported that $\mathrm{A} \beta$-induced CEC apoptosis was associated with the induction of Bim (Yin et al., 2002b). Bim is an apoptotic initiator belonging to the $\mathrm{BH} 3$-only proteins. In this study, we note that bim mRNA expression was selectively elevated in cerebral microvessels iso- 
lated from 18-month-old APPsw mutant transgenic mice with phenotypic presentation of CAA compared with the agematched wild-type animals. No increased expression of other genes in the BH3-only family ( $b i d, b a d, b m f$, and $d p 5$ ) was noted. APPsw mice develop age-dependent accumulation in parenchymal and vascular amyloid, reproducing many of the major pathological features of $\mathrm{AD}$ and $\mathrm{CAA}$ (Hsiao et al., 1996). At 18 months of age, APPsw mice demonstrate prominent amyloid accumulation surrounding cortical arterioles, and microvascular hemorrhage is evident throughout the cortex (Fryer et al., 2003; Lee et al., 2003), suggesting extensive cerebrovascular degeneration. Therefore, the selective induction of bim suggests that this apoptotic initiator of the $\mathrm{BH} 3$-only family may play a role in cerebrovascular degeneration. To investigate the regulatory mechanism of bim expression in CAA, we studied the effects of $\mathrm{A} \beta$ on mouse CECs. Paralleling the finding in amyloid-laden vessels in APPsw mice, selective bim induction was observed in CECs treated with $A \beta$; all three isoforms of bim were induced in a time-dependent manner, peaking at $4 \mathrm{~h}$.

FKHRL1, a member of the forkhead transcription factor family, transactivates bim expression after its dephosphorylation (Burgering and Kops, 2002; Gilley et al., 2003). In viable cells, forkhead protein activity is kept in phosphorylated and inactive state by the survival-promoting kinase Akt (Brunet et al., 1999; Tang et al., 1999). Dephosphorylation and the consequent inactivation of Akt by protein phosphatases releases pro-apoptotic proteins such as forkhead proteins from the phosphorylated and inactive state to initiate apoptotic processes (Ugi et al., 2004; Gao et al., 2005). $A \beta$ induction of bim expression was associated with the dephosphorylation of Akt (at Ser 473 and Thr 308). This was accompanied by dephosphorylation and activation of FKHRL1, leading to an increase in DNA binding activity of FKHRL1. Consensus binding sites for FKHRL1 are present in the promoter region of bim. FKHRL1 activation (via dephosphorylation) has been shown to increase bim expression after cytokine withdrawal in lymphocytes (Dijkers et al., 2000) and IGF-I withdrawal in cerebellar granule neurons (Linseman et al., 2002). We also found that increasing Akt activity by viral gene transfer attenuated $\mathrm{A} \beta$-induced increase in FKHRL1 DNA binding activity and bim induction in CECs, suggesting that FKHRL1 activity is negatively regulated via phosphorylation by Akt. These results are consistent with previous reports that phosphorylation of FKHRL1 by Akt results in FKHRL1 sequestration in cytosol by 14-3-3 (Brunet et al., 1999; Tang et al., 1999). The phorphorylation state of any protein is the result of a net balance between kinase activity and phosphatase activity.

In a previous study, we have demonstrated that $A \beta$ activated
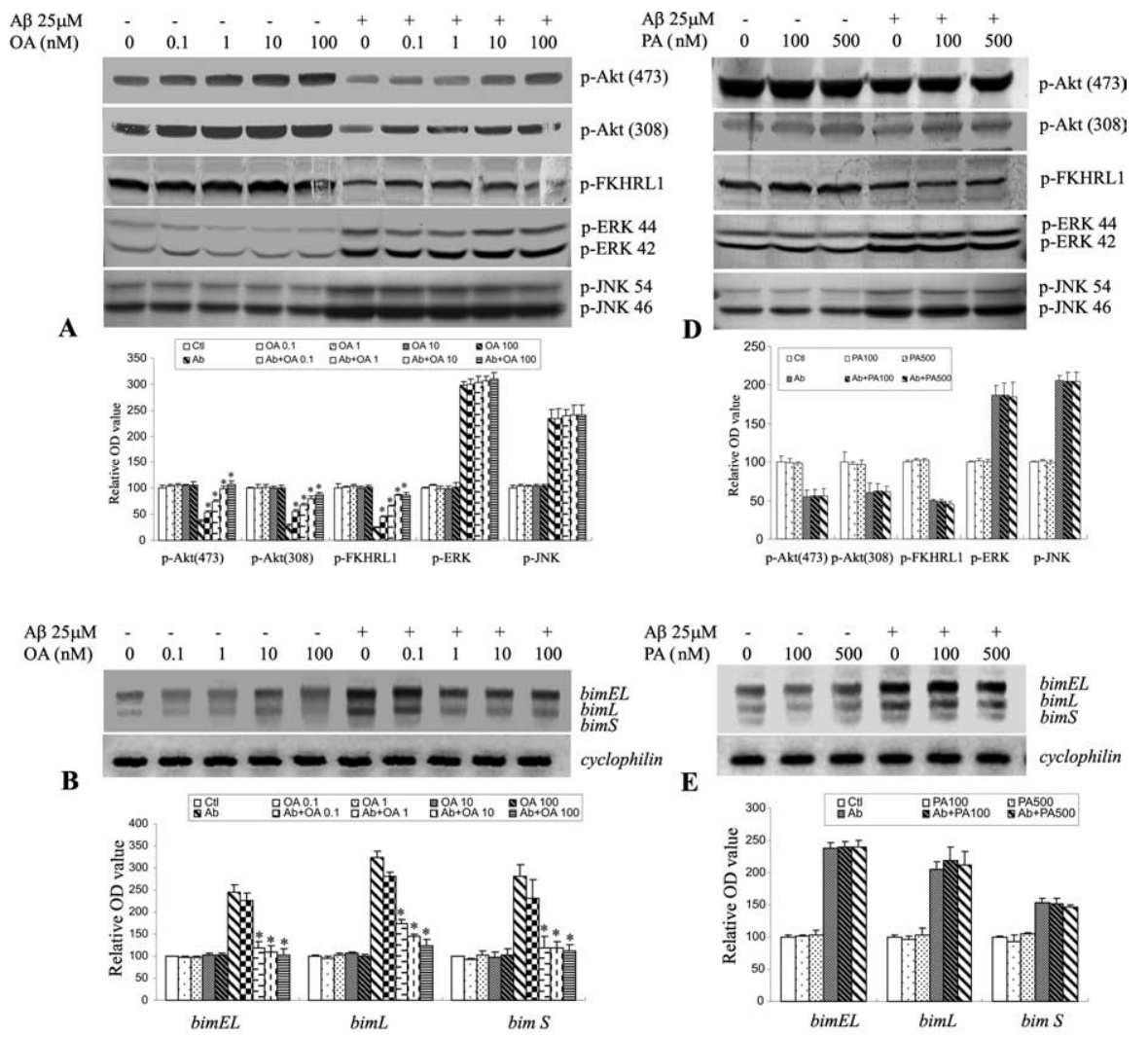

Figure 5. PP2A inhibition reduced dephosphorylation of Akt and FKHRL1, subsequent induction of bim, and CEC death. CECS, in a dose-dependent manner. However, $O A$ had no effect on dephosphorylation of ERK and JNK. $B, O A$ also decreased subsequent 列 $(\boldsymbol{E})$, or $A \beta$-induced $C E C$ death $(\boldsymbol{F})$. The quantitative analysis of data with representative blots shown in $\boldsymbol{A}, \boldsymbol{B}, \boldsymbol{D}$, and $\boldsymbol{E}$ is in the respective bottom panels. Data are expressed as mean \pm SD. ${ }^{*} p<0.05$ versus the $A \beta$-treated group.

nSMase to generate ceramide (Lee et al., 2004; Yang et al., 2004). Ceramide, a lipid mediator of apoptosis, mediates $\mathrm{A} \beta$-induced $\mathrm{CEC}$ death (Yang et al., 2004). Here, we report that $\mathrm{A} \beta$ induced a rapid activation of the CAPP PP2A. Inhibition of PP2A with a selective PP2A inhibitor, OA, or PP2A gene knockdown by an RNA interference (RNAi) strategy attenuated $\mathrm{A} \beta$-induced dephosphorylation of Akt and FKHRL1. Furthermore, PP2A inhibition prevented bim activation and subsequent CEC death induced by $\mathrm{A} \beta$. PA, a specific inhibitor of PP1, did not alter the phosphorylation of Akt and FKHRL1, induction of bim, or cell death induced by $\mathrm{A} \beta$. Collectively, these results demonstrate for the first time that PP2A, but not PP1, is selectively involved (at least in part) in the induction of bim-mediated apoptosis via the Akt/FKHRL1 pathway. We also found that inhibition of ceramide synthesis by a selective nSMase inhibitor (3-OMe-SM) prevented PP2A activation by A $\beta$. Thus, we have established the following pathway for $\mathrm{A} \beta$-induced $\mathrm{CEC}$ apoptosis: $\mathrm{A} \beta \rightarrow$ 
A
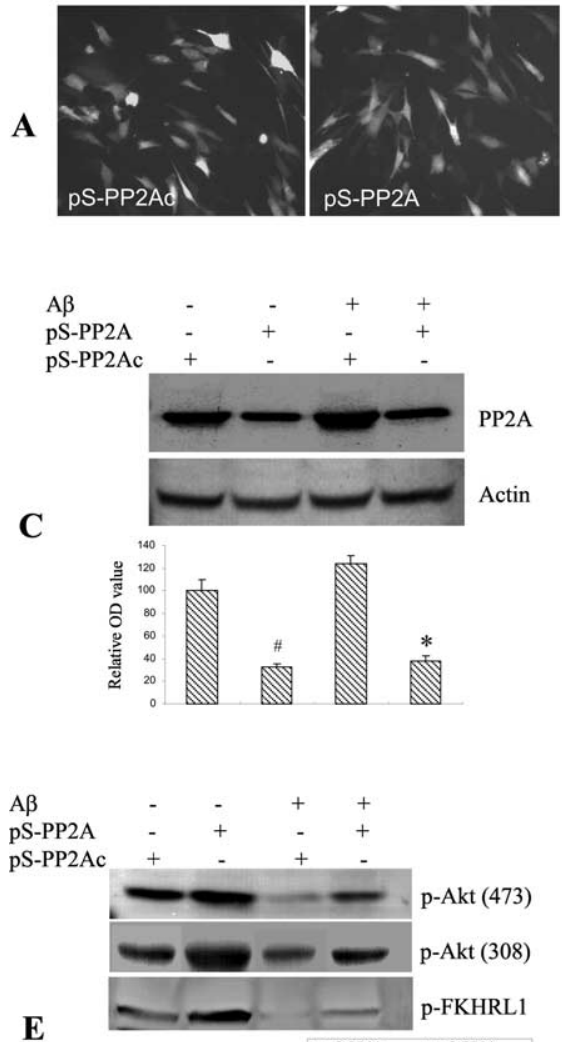

$\mathbf{E}$

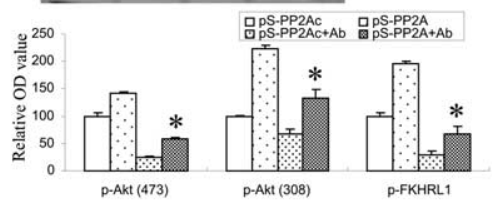

G

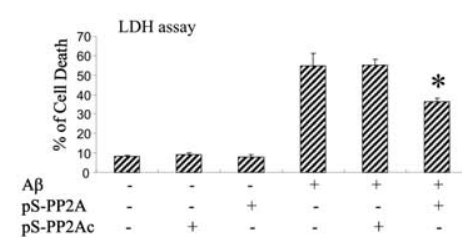

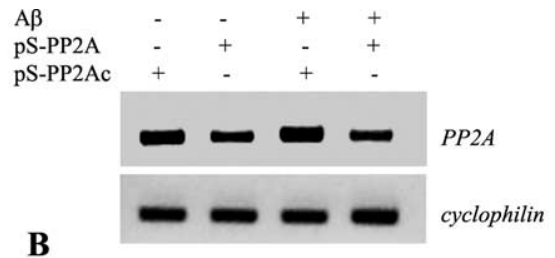

B
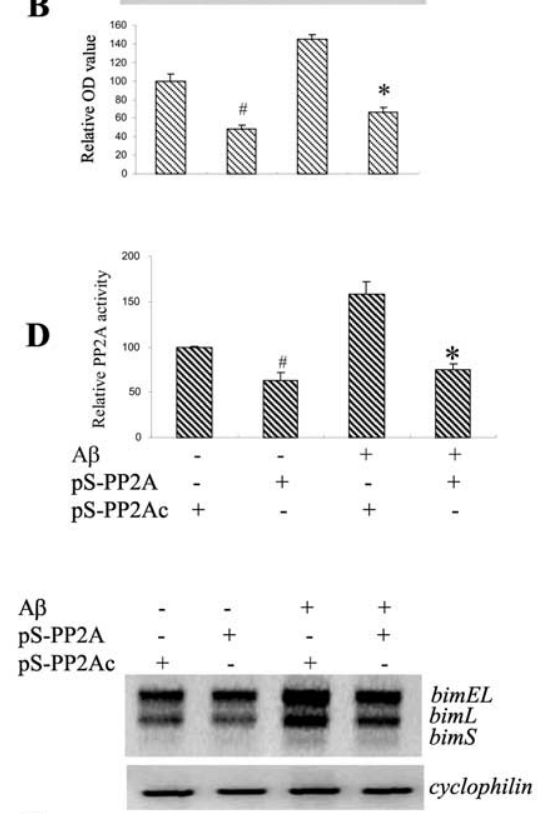

F
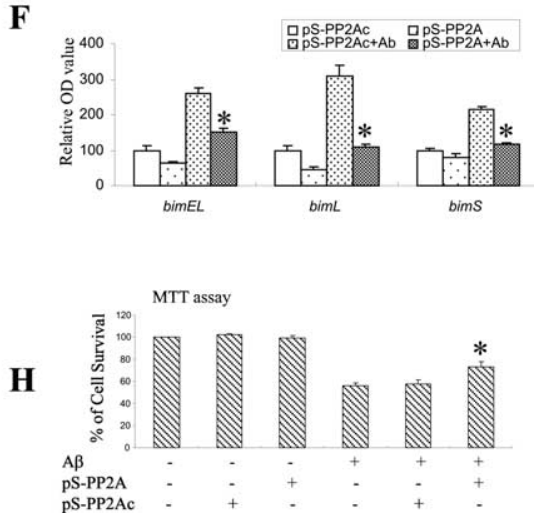

tion of selective substrates, including ERKs and the JNKs. ERKs and JNKs may be activated by cellular stress or apoptotic signals (Millward et al., 1999; Shanley et al., 2001; Silverstein et al., 2002; Kins et al., 2003). We and other investigators have also reported that activation of the JNK signaling pathway may contribute to Bimmediated apoptosis in CECs in vitro (Yin et al., 2002b) and neuronal apoptosis after transient focal cerebral ischemia (Okuno et al., 2004). To determine whether MAPK signaling is actively associated with PP2A regulation of bim-mediated apoptosis in CECs after $A \beta$ exposure, we examined the effects of PP2A inhibition on dephosphorylation of ERK and JNK. Treatment of CEC with a PP2A inhibitor (OA) or a PP1 inhibitor (PA) at different doses failed to lead to the alteration of phospho-ERK/JNK levels (Fig. 5A,D), implying that these pathways may not be involved in PP2A-modulated transactivation of bim in CECs. Additional studies are needed to determine the relative importance of PP2A-dependent and -independent mechanisms in Bim-mediated CEC death induced by $\mathrm{A} \beta$.

In the present study, we found that PP2A activity was elevated in cultured CECs after $A \beta$ exposure as well as in cerebral microvessels isolated from 18-monthold APPsw transgenic mice. PP2A, a serine/threonine phosphatase, is involved in a number of signaling pathways in mammalian cells (Mumby and Walter, 1993). It is a heterotrimer containing a catalytic subunit (C), a structural scaffolding subunit (A), and a regulatory subunit (B). The catalytic and structural subunits, forming the catalytic complex of the phosphatase, are evolutionary conserved (Stone et al., 1987; Hemmings et al., 1990; Mumby and Walter, 1993); only two closely related isoforms ( $\alpha$ and $\beta$ ) of both subunits have been identified ( $\mathrm{A} \alpha$ and $\mathrm{C} \alpha$ are the most abundant). However, there are four known families of diverse B-subunits (B, B', $\mathrm{B}^{\prime \prime}$, or $\mathrm{B}^{\prime \prime \prime}$ family) that vary in expression temporally and by tissue types (Ruediger et al., 1991; Mumby and Walter, 1993; McCright and Virshup, 1995; Csortos et al., 1996). Substrate specificity seems to be determined by the B-subunits (Cegielska et al., 1994). Moreover, there are multiple isoforms $(\alpha, \beta, \gamma$, $\delta$, etc.) and splice variants for each family, allowing for a wide variety of possible PP2A holoenzymes. The B-subunits may

nSMase $\rightarrow$ ceramide $\rightarrow$ PP2A activation $\rightarrow$ Akt dephosphorylation $\rightarrow$ FKHRL1 dephosphorylation $\rightarrow$ bim induction $\rightarrow$ apoptotic cascade $\rightarrow$ apoptosis.

Recent studies have suggested that PP2A may play a critical role in the regulation of the MAPK cascades by dephosphoryla- also target the PP2A catalytic complex to intracellular sites such as microtubules (Sontag et al., 1995) or the nucleus (McCright et al., 1996a,b). These features of the PP2A regulatory B-subunits suggest that it is the B-subunit that defines PP2A isoforms and their physiological roles. In this study, we found that mouse CECs 
express the structural subunit (PP2A A $\alpha$ ) and many of the regulatory $\mathrm{B}$-subunit families: PP2A B $\alpha \beta \gamma(\mathrm{B}), \mathrm{B} 56 \alpha\left(\mathrm{B}^{\prime}\right), \mathrm{C} \alpha \beta$ $\left(B^{\prime \prime}\right)$. Protein levels of all of the subunits remained unchanged after $\mathrm{A} \beta$ treatment for up to $48 \mathrm{~h}$. To determine which subunit might be involved in the regulation of Akt, we performed coimmunoprecipitation experiments with subunit-selective antibodies in CECs grown in the presence and absence of $A \beta$. The structural subunit PP2A $\mathrm{A} \alpha$ coimmunoprecipitated with anti-Akt antibodies in CECs treated with $\mathrm{A} \beta$ but not in control cultures. Furthermore, regulatory subunits from the $\mathrm{B}(\mathrm{B} \alpha \beta \gamma), \mathrm{B}^{\prime}$ $(\mathrm{B} 56 \alpha)$, and $\mathrm{B}^{\prime \prime}$ family (PP2A C $\left.\alpha \beta\right)$ coimmunoprecipitated with anti-Akt antibodies in A $\beta$-treated CECs. However, only the $B^{\prime \prime}$ subunit showed an increase in coimmunoprecipitation after $\mathrm{A} \beta$ treatment, suggesting that this subunit is selectively involved in regulating Akt phosphorylation, subsequent bim induction, and apoptotic cell death resulting from $\mathrm{A} \beta$ toxicity.

In conclusion, the present study suggests a novel role for PP2A, a ceramideactivated protein phosphatase, in mediating $\mathrm{A} \beta$-induced apoptosis in CECs. Our data suggest that PP2A may mediate $\mathrm{A} \beta$-induced bim expression and subsequent apoptotic cascades via the Akt/FKHRL1 signaling pathway. That importance of bim upregulation by PP2A in cerebrovascular degeneration is suggested by increased PP2A activity and bim expression in microvascular preparations isolated from APPsw mice. The elucidation of the signaling events involved in $\mathrm{A} \beta$-induced CEC death may be important for understanding molecular mechanisms of cerebrovascular degeneration to design effective strategies to attenuate the pathogenesis of CAA.

\section{References}

Behl C, Davis JB, Lesley R, Schubert D (1994) Hydrogen peroxide mediates amyloid beta protein toxicity. Cell 77:817-827.

Blanc EM, Toborek M, Mark RJ, Hennig B, Mattson MP (1997) Amyloid beta-peptide induces cell monolayer albumin permeability, impairs glucose transport, and induces apoptosis in vascular endothelial cells. J Neurochem 68:1870-1881.

Bouillet P, Zhang LC, Huang DC, Webb GC, Bottema CD, Shore P, Eyre HJ, Sutherland GR, Adams JM (2001) Gene structure alternative splicing, and chromosomal localization of pro-apoptotic Bcl-2 relative Bim. Mamm Genome 12:163-168.

Brugg B, Michel PP, Agid Y, Ruberg M (1996) Ceramide induces apoptosis in cultured mesencephalic neurons. J Neurochem 66:733-739.

Brunet A, Bonni A, Zigmond MJ, Lin MZ, Juo P, Hu LS, Anderson MJ, Arden KC, Blenis J, Greenberg ME (1999) Akt promotes cell survival by phosphorylating and inhibiting a Forkhead transcription factor. Cell 96:857-868.

Burgering BM, Kops GJ (2002) Cell cycle and death control: long live Forkheads. Trends Biochem Sci 27:352-360.

Cegielska A, Shaffer S, Derua R, Goris J, Virshup DM (1994) Different oligomeric forms of protein phosphatase $2 \mathrm{~A}$ activate and inhibit simian virus 40 DNA replication. Mol Cell Biol 14:4616-4623.

Chalfant CE, Kishikawa K, Mumby MC, Kamibayashi C, Bielawska A, Hannun YA (1999) Long chain ceramides activate protein phosphatase-1 and protein phosphatase-2A. Activation is stereospecific and regulated by phosphatidic acid. J Biol Chem 274:20313-20317.

Cohen P (1989) The structure and regulation of protein phosphatases. Annu Rev Biochem 58:453-508.
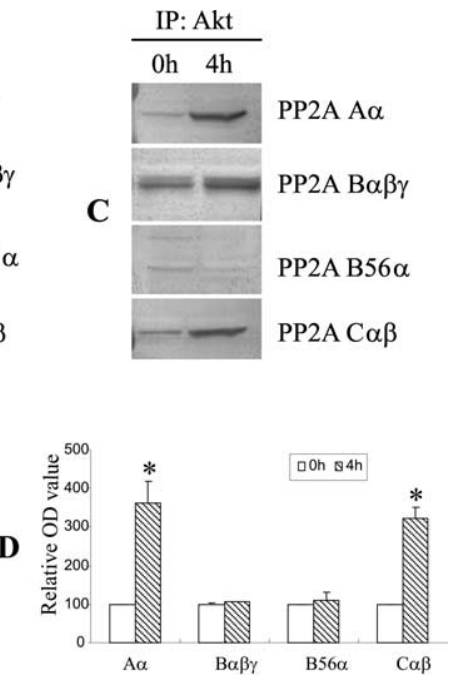
Kelekar A, Thompson CB (1998) Bcl-2-family proteins: the role of the BH3 domain in apoptosis. Trends Cell Biol 8:324-330.

Kins S, Kurosinski P, Nitsch RM, Gotz J (2003) Activation of the ERK and JNK signaling pathways caused by neuron-specific inhibition of PP2A in transgenic mice. Am J Pathol 163:833-843.

Kishikawa K, Chalfant CE, Perry DK, Bielawska A, Hannun YA (1999) Phosphatidic acid is a potent and selective inhibitor of protein phosphatase 1 and an inhibitor of ceramide-mediated responses. J Biol Chem 274:21335-21341.

Law B, Rossie S (1995) The dimeric and catalytic subunit forms of protein phosphatase $2 \mathrm{~A}$ from rat brain are stimulated by $\mathrm{C} 2$-ceramide. J Biol Chem 270:12808-12813.

Lee JM, Yin KJ, Hsin I, Chen S, Fryer JD, Holtzman DM, Hsu CY, Xu J (2003) Matrix metalloproteinase- 9 and spontaneous hemorrhage in an animal model of cerebral amyloid angiopathy. Ann Neurol 54:379-382.

Lee JT, Xu J, Lee JM, Ku G, Han X, Yang DI, Chen S, Hsu CY (2004) Amyloid-beta peptide induces oligodendrocyte death by activating the neutral sphingomyelinase-ceramide pathway. J Cell Biol 164:123-131.

Linseman DA, Phelps RA, Bouchard RJ, Le SS, Laessig TA, McClure ML, Heidenreich KA (2002) Insulin-like growth factor-I blocks Bcl-2 interacting mediator of cell death (Bim) induction and intrinsic death signaling in cerebellar granule neurons. J Neurosci 22:9287-9297.

Loo DT, Copani A, Pike CJ, Whittemore ER, Walencewicz AJ, Cotman CW (1993) Apoptosis is induced by beta-amyloid in cultured central nervous system neurons. Proc Natl Acad Sci USA 90:7951-7955.

Mangoura D, Dawson G (1998) Programmed cell death in cortical chick embryo astrocytes is associated with activation of protein kinase PK60 and ceramide formation. J Neurochem 70:130-138.

McCright B, Virshup DM (1995) Identification of a new family of protein phosphatase 2A regulatory subunits. J Biol Chem 270:26123-26128.

McCright B, Brothman AR, Virshup DM (1996a) Assignment of human protein phosphatase $2 \mathrm{~A}$ regulatory subunit genes b56alpha, b56beta, b56gamma, b56delta, and b56epsilon (PPP2R5A-PPP2R5E), highly expressed in muscle and brain, to chromosome regions 1q41, 11q12, 3p21, 6p21.1, and 7p11.2 $\rightarrow$ p12. Genomics 36:168-170.

McCright B, Rivers AM, Audlin S, Virshup DM (1996b) The B56 family of protein phosphatase 2A (PP2A) regulatory subunits encodes differentiation-induced phosphoproteins that target PP2A to both nucleus and cytoplasm. J Biol Chem 271:22081-22089.

Millward TA, Zolnierowicz S, Hemmings BA (1999) Regulation of protein kinase cascades by protein phosphatase 2A. Trends Biochem Sci 24:186-191.

Mumby MC, Walter G (1993) Protein serine/threonine phosphatases: structure, regulation, and functions in cell growth. Physiol Rev 73:673-699.

Obeid LM, Linardic CM, Karolak LA, Hannun YA (1993) Programmed cell death induced by ceramide. Science 259:1769-1771.

Okuno S, Saito A, Hayashi T, Chan PH (2004) The c-Jun N-terminal protein kinase signaling pathway mediates Bax activation and subsequent neuronal apoptosis through interaction with Bim after transient focal cerebral ischemia. J Neurosci 24:7879-7887.

Pardridge WM, Eisenberg J, Yamada T (1985) Rapid sequestration and degradation of somatostatin analogues by isolated brain microvessels. J Neurochem 44:1178-1184.

Perlmutter LS, Myers MA, Barron E (1994) Vascular basement membrane components and the lesions of Alzheimer's disease: light and electron microscopic analyses. Microsc Res Tech 28:204-215.

Preston JE, Hipkiss AR, Himsworth DT, Romero IA, Abbott JN (1998) Toxic effects of beta-amyloid(25-35) on immortalised rat brain endothelial cell: protection by carnosine, homocarnosine and beta- alanine. Neurosci Lett 242:105-108.

Price JM, Sutton ET, Hellermann A, Thomas T (1997) Beta-amyloid induces cerebrovascular endothelial dysfunction in the rat brain. Neurol Res 19:534-538.

Ruediger R, Van Wart Hood JE, Mumby M, Walter G (1991) Constant ex- pression and activity of protein phosphatase $2 \mathrm{~A}$ in synchronized cells. Mol Cell Biol 11:4282-4285.

Shanley TP, Vasi N, Denenberg A, Wong HR (2001) The serine/threonine phosphatase, PP2A: endogenous regulator of inflammatory cell signaling. J Immunol 166:966-972.

Silverstein AM, Barrow CA, Davis AJ, Mumby MC (2002) Actions of PP2A on the MAP kinase pathway and apoptosis are mediated by distinct regulatory subunits. Proc Natl Acad Sci USA 99:4221-4226.

Sontag E, Nunbhakdi-Craig V, Bloom GS, Mumby MC (1995) A novel pool of protein phosphatase $2 \mathrm{~A}$ is associated with microtubules and is regulated during the cell cycle. J Cell Biol 128:1131-1144.

Stone SR, Hofsteenge J, Hemmings BA (1987) Molecular cloning of cDNAs encoding two isoforms of the catalytic subunit of protein phosphatase $2 \mathrm{~A}$. Biochemistry 26:7215-7220.

Suo Z, Fang C, Crawford F, Mullan M (1997) Superoxide free radical and intracellular calcium mediate A beta(1-42) induced endothelial toxicity. Brain Res 762:144-152.

Tang ED, Nunez G, Barr FG, Guan KL (1999) Negative regulation of the forkhead transcription factor FKHR by Akt. J Biol Chem 274:16741-16746.

Ugi S, Imamura T, Maegawa H, Egawa K, Yoshizaki T, Shi K, Obata T, Ebina Y, Kashiwagi A, Olefsky JM (2004) Protein phosphatase 2A negatively regulates insulin's metabolic signaling pathway by inhibiting Akt (protein kinase B) activity in 3T3-L1 adipocytes. Mol Cell Biol 24:8778-8789.

Whitfield J, Neame SJ, Paquet L, Bernard O, Ham J (2001) Dominantnegative c-Jun promotes neuronal survival by reducing BIM expression and inhibiting mitochondrial cytochrome c release. Neuron 29:629-643.

Wisniewski HM, Wegiel J (1995) The neuropathology of Alzheimer's disease. Neuroimaging Clin N Am 5:45-57.

Wisniewski HM, Wegiel J, Vorbrodt AW, Mazur-Kolecka B, Frackowiak J (2000) Role of perivascular cells and myocytes in vascular amyloidosis. Ann NY Acad Sci 903:6-18.

Xu J, Qu ZX, Moore SA, Hsu CY, Hogan EL (1992) Receptor-linked hydrolysis of phosphoinositides and production of prostacyclin in cerebral endothelial cells. J Neurochem 58:1930-1935.

Xu J, Yeh CH, Chen S, He L, Sensi SL, Canzoniero LM, Choi DW, Hsu CY (1998) Involvement of de novo ceramide biosynthesis in tumor necrosis factor- $\alpha /$ cycloheximide-induced cerebral endothelial cell death. J Biol Chem 273:16521-16526.

Xu J, Chen S, Ku G, Ahmed SH, Chen H, Hsu CY (2001) Amyloid beta peptide-induced cerebral endothelial cell death involves mitochondrial dysfunction and caspase activation. J Cereb Blood Flow Metab 21:702-710.

Yang DI, Yeh CH, Chen S, Xu J, Hsu CY (2004) Neutral sphingomyelinase activation in endothelial and glial cell death induced by amyloid betapeptide. Neurobiol Dis 17:99-107.

Yankner BA (1996) Mechanisms of neuronal degeneration in Alzheimer's disease. Neuron 16:921-932.

Yankner BA, Dawes LR, Fisher S, Villa-Komaroff L, Oster-Granite ML, Neve RL (1989) Neurotoxicity of a fragment of the amyloid precursor associated with Alzheimer's disease. Science 245:417-420.

Yin KJ, Chen SD, Lee JM, Xu J, Hsu CY (2002a) ATM gene regulates oxygen-glucose deprivation-induced nuclear factor-kappaB DNAbinding activity and downstream apoptotic cascade in mouse cerebrovascular endothelial cells. Stroke 33:2471-2477.

Yin KJ, Lee JM, Chen SD, Xu J, Hsu CY (2002b) Amyloid- $\beta$ induces Smac release via AP-1/Bim activation in cerebral endothelial cells. J Neurosci 22:9764-9770.

Zheng WH, Kar S, Quirion R (2000) Insulin-like growth factor-1-induced phosphorylation of the forkhead family transcription factor FKHRL1 is mediated by Akt kinase in PC12 cells. J Biol Chem 275:39152-39158.

Zlokovic BV, Mackic JB, Wang L, McComb JG, McDonough A (1993) Differential expression of Na,K-ATPase alpha and beta subunit isoforms at the blood-brain barrier and the choroid plexus. J Biol Chem 268:80198025 . 